\title{
Effect that Smell Presentation Has on an Individual in Regards to Eye Catching and Memory
}

\author{
Akira Tomono Member (Tokai University, tomono@keyaki.cc.u-tokai.ac.jp) \\ Koyori Kanda Non-member (Tokai University, 8adrm013@mail.tokai-u.jp) \\ Syunya Otake Non-member (Tokai University,8adrm008@mail.tokai-u.jp)
}

Keywords : image, smell presentation, realistic sensation, gaze detection, eye catching property, memory

\section{Introduction}

If a person's eyes are greater attracted to the target objects by matching the smell to an important scene of a movie or commercial image, the value of the image contents will rise. In this paper, we attempt to describe the image system that can also present smells, and the reason behind the improvement, from gaze point analysis, of the presence of smell when it is matched to the image. Moreover, we investigated the effect on the memory by putting the smell on the image using immersive virtual reality system (HoloStage ${ }^{\mathrm{TM}}$ ).

\section{Display System that Synchronizes Image and Smell}

In our proposed image system, the image and smell presentation information are encoded on a medium such as a DVD, and necessary smells for the contents are offered by the set. During playback, the image and smell presentation information is decoded, a suitable smell is chosen from the smell set, and then presented. An air cannon type olfactory display that can project a mass of air containing a smell to the user's nose from a small distance is used in this system.

\section{Experiment of Evaluating Eye Catching Property}

The image with the smell of food was presented, the eye movement detection data was analyzed, and the relationship between the eye catching and the presence of the smell was examined. In the experiment, some sight objects are displayed on the screen, and the smell related to one of the objects in them was presented (Figure 1). Then differences of the object gazed at by the smell presence were investigated from the gaze point analysis.

As for the result of the case in which the movement of the image was slight, the subject's gaze was strongly induced to the sight object that related to the smell and it was carefully observed. In the case that the objects in the image had movement, the moving object was mainly gazed at. However, when the smell was presented, not only the moving object but also objects related to the smell were also gazed at. The relationship between the eye catching property and the position of the sight object was examined using the image with the scene where someone eats three kinds of fruits shown in Figure 2. In both of the two cases where the fruit objects with smell were at the center (Image(i))or at the side (Image(ii)) of the screen, these objects were gazed at for a long time once releasing their smells (Figure 3). When the smell was not released, the gaze moved actively to try and receive a lot of information from the entire screen. On the other hand, when the smell was inserted, the subject was interested in the object and there was a tendency for their gaze to stay within the narrow area surrounding the image. Through the introspective testimonials of the subjects wanting to eat the fruit or recollecting a similar experience in the past, they said themselves that the presence of the need to eat increases and it is possible to concentrate longer on the image by inserting the object's smell.

\section{Effect on Memory by Smell Presentation}

Smells were put on objects in a virtual space (11 kinds of flowers in the virtual flower shop), and we tested the effect smell has on the memory. In the experiment when there was no smell, the correct answer rate of a well-known flower was high. Furthermore, in the case of the experiment with smell, the correct answer rate for the flower with a given smell was higher, and even though the difference was not large, the average correct answer rate improved from $23 \%$ (without smell) to $36 \%$ (with smell). It was a change of $13 \%$.

\section{Conclusion}

When a suitable smell for the sight object was selected, it was observed that the person's gaze focused more on the object, and it was memorized more easily compared with a scentless case. It seems that the viewer obtains the information actively by reacting to its smell. This research is currently underway in our laboratory for later application in the fields of digital signature mark-up, Internet advertising, etc.

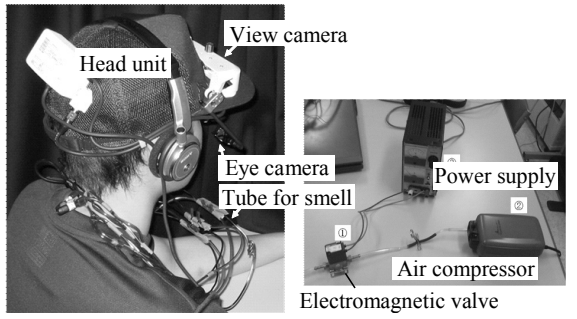

Fig. 1. Gaze detection system and smell presentation device

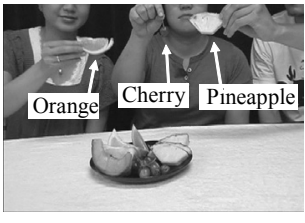

Image (i)

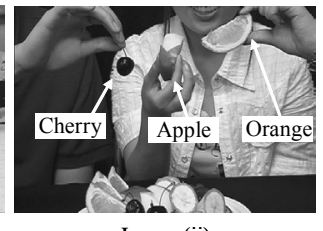

Image (ii)
(Smell of orenge was presented.) (Smell of apple was presented.)

Fig. 2. Experiment that inserts one smell on the scene where three people are eating three kinds of fruits
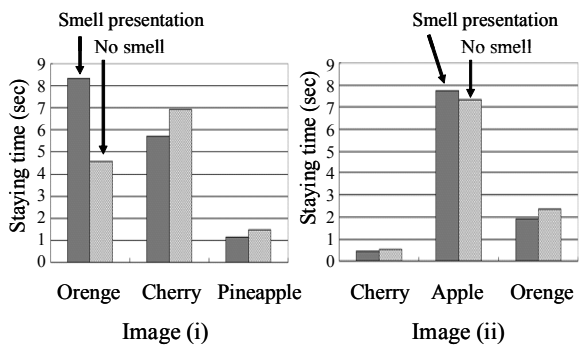

Fig. 3. Analysis results of gaze staying time 
映像への香り付加が誘目性と記憶に与える影響

\author{
正 員 伴野＼cjkstart明*＼cjkstart非会員 神田こより** \\ 非会員 大竹 俊弥**
}

\title{
Effect that Smell Presentation Has on an Individual in Regards to Eye Catching and Memory \\ Akira Tomono*, Member, Koyori Kanda**, Non-member, Syunya Otake**, Non-member
}

\begin{abstract}
If a person's eyes are greater attracted to the target objects by matching the smell to an important scene of a movie or commercial image, the value of the image contents will rise. In this paper, we attempt to describe the image system that can also present smells, and the reason behind the improvement, from gaze point analysis, of the presence of smell when it is matched to the image. The relationship between the eye catching property and the position of the sight object was examined using the image with the scene where someone eats three kinds of fruits. These objects were gazed at for a long time once releasing their smells. When the smell was not released, the gaze moved actively to try and receive a lot of information from the entire screen. On the other hand, when the smell was inserted, the subject was interested in the object and there was a tendency for their gaze to stay within the narrow area surrounding the image. Moreover, we investigated the effect on the memory by putting the smell on the flowers in the virtual flower shop using immersive virtual reality system (HoloStage $\left.{ }^{\mathrm{TM}}\right)$. It was memorized more easily compared with a scentless case. It seems that the viewer obtains the information actively by reacting to its smell.
\end{abstract}

キーワード : 映像, 香り, 臨場感, 視線検出, 誘目性, 記憶

Keywords : image, smell presentation, realistic sensation, gaze detection, eye catching property, memory

\section{1. はじめに}

従来，映画やテレビなどの映像メディアは主として映像 と音声によって構成されてきた。しかし，人間は普段の生 活の中で五感すべてを使って得た情報から自分の状況を把 握し, 次の行動を判断している。今後, 情報メディアによ って再現されるバーチャル空間が現実と同じように知覚さ れ, 高度な利用が図られるためには, 視覚, 聴覚以外の情 報も提示していくことが重要と思われる。中でも，嗅覚刺 激は，人の記憶や感情に直接作用するため，映像に香りを 適切に付加できれば，臨場感向上やコンテンツの内容理解 の補助として大きな潜在的可能性をもっている。例えば, 映画の重要シーンやコマーシャル映像において, 香りを付 加することによって，人の目を引き付け，記憶に結びつけ ることができればコンテンツの付加価值は高まる。

このため, 最近様々な機関で, 香りの発生方法, 調合提

* 東海大学情報通信学部情報メディア学科

干259-1292 神奈川県平塚市北金目 1117

Department of Information Media Technology， School of Information and Telecommunication Engineering, Tokai University. 1117 Kitakaname, Hiratsuka-shi, Kanagawa 259-1292

** 東海大学大学院工学研究科

干259-1292 神奈川県平塚市北金目 1117

Graduate school of Engineering, Tokai University.

1117 Kitakaname, Hiratsuka-shi, Kanagawa 259-1292
示方法, 映像への香り提示方法とその効果などの研究が行 われている(1)。我々の研究としては, 利用者に適切なタイミ ングで微量の香りを提示できる空気砲式香り発生装置を開 発し (2)(3), 映像に香りを付加する実験によって, 臨場感や内 容理解への影響 (効果) を調查してきた。その結果, 映画 などストーリー性のある映像の主要場面に適切な香りを付 加する実験では，香り提示によってその場面への興味や関 心が高まり, 瞳孔の散大が起きやすいことを明らかにした ${ }^{(4)}$ 。 また, 没入型バーチャルリアリティ装置などで表現された 地理空間映像に香りを付加すると, 道順やその場面の構造 物が記憶に残り易いことを示した ${ }^{(5)(6)}$ 。現在，このような香 り提示効果の理由について検討しているが，一つには，嗅 覚刺激によって人の情報獲得戦略に変化が生じることが考 えられる。つまり，香り提示によって香りを発する物体へ の関心が高まり，注意深く観察するようになるのではない かと考えている。

注目度を表す要素の一つに誘目性がある。誘目性とは無 意識に人の目を引き付ける性質のことで，従来，色の違い， 明暗の違い, 物体の大きさ, 動くものなどにその性質があ ることが知られている。例えば, 信号機の色, 郵便ポスト の赤色などは, 様々なもので溢れる街中でも誘目性が高く, 比較的目に付きやすいように設計されている。誘目性の研 
究例としては，画像の印象推定処理のために，画像を色相， 明度, 彩度などのパラメータで評価し, 誘目性の高い領域 を抽出する研究 ${ }^{(7)(8)}$ や, 視線移動を伴う際の見つけやすさを 動的状態の誘目性，十分な時間をかけてみる場合のみつけ やすさを静的状態の誘目性と定義し, 動的な誘目性に寄与 する因子を検討する研究(9)などが存在する。このように誘目 性は主に視覚について研究されているが，香り付き視覚対 象に関する誘目性について調査された例は少ない。

そこで，本論文では，香り提示が可能な映像システムに ついて述べ，映像に香りを付加した場合の臨場感の向上に ついて, その理由を注視点の変化から分析する。香り付加 対象に動きがある場合とない場合での注視点分布の比較,

香り付加対象が画面中央にある場合と周辺にある場合での 視線停留時間分析などから，香りの誘目性，又は，鑑賞者 の情報獲得戦略について考察する。また，映像に香りを付 けることの記憶への影響について, 没入型 VR 装置を用いて 実験した結果を報告する。

\section{2. 香り付き映像提示システムと臨場感の向上}

図 1 は, 映画などストーリー性のある映像に香り提示情 報を付けたコンテンツを上映するシステムの概念である ${ }^{(10)}$ 。 香り情報提示は，映像を制作する際に臨場感を高める目的 で，又は，表現意図の理解を助ける目的で重要なシーンに 付与される。映像及び香り情報は DVD などの媒体に記録さ れ提供されるが，この際，当該コンテンツに必要な香りが セットで提供される。再生の際は, 映像と共に香り提示情 報が読み取られ, 香りセットの中から適当な香りが選択さ れ鑑賞者に提示される。

この概念の有効性を検証するため，システムを部分的に 試作し, 動作確認実験, 及び, 臨場感評価実験を行った。 非装着な香り提示手段としては空気砲の原理を用いた装置 を使用した。香り提示シーンの直前で，砲筒に香りを供給 し空気砲を動作すると, 砲筒の香りは渦輪となって空中を 飛行し鑑賞者の鼻先に提示される。この装置は, 香料を空 間的にも時間的にもピンポイントで提示できる。また，使 用する香りが微量のため, 当該香りが鑑賞者に吸われる, 又は, 拡散すると後に残らない特徽があり, 従って, 香り の切り替えに有利である。しかし，その特徽は，逆に鑑賞 者が吸気状態にないときに香りが飛んでくると受容されな いと言う問題を生じる。これに対しては, 図 1 に示すよう に呼吸検出手段を併用する, 又は，吸気を予測する手段を 組み合わせることが有効であることを確認した (3)。

図 2 は, 吸気予測による香り提示の例である。呼吸の平 均的な間隔を予め計測しておき, 呼気を小型マイクロホン などで検出し，当該呼気の後に平均的な呼吸間隔時間をお いて吸気が来ると予測して香りを提示する方法を用いる と, 一定間隔で繰り返して香りを提示する場合に比べて, 香りが受容される確率を $50 \%$ 以上改善できる。また, 鼻腔 吸引 (Sniffing) を促すような映像コンテンツを用い, その動 作モデルを用いて吸気を予測し，香りを提示する方法も同

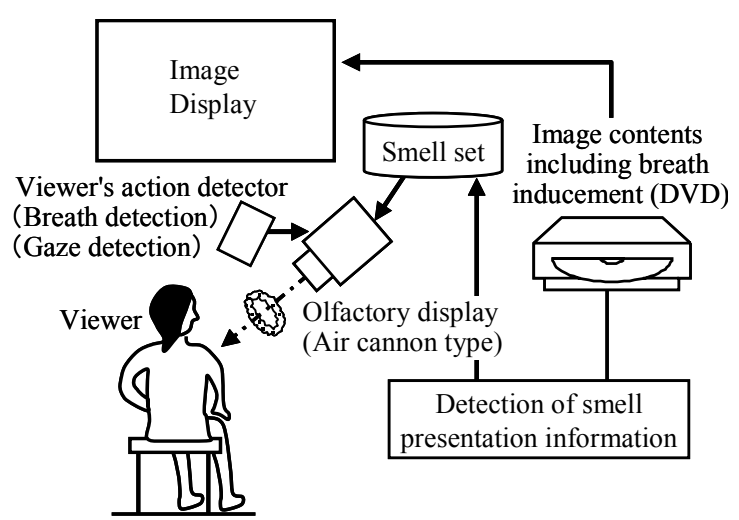

Fig. 1. Display system that synchronizes image and smell.

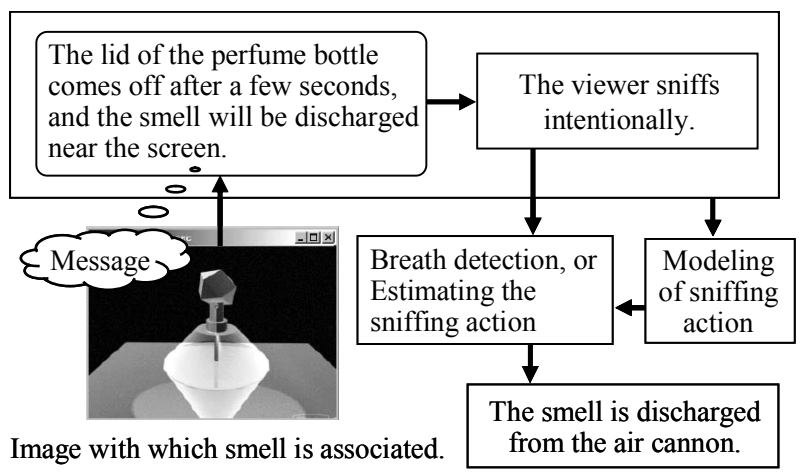

Fig. 2. An example of smell presentation using estimating the sniffing action.

様に有効であった。

映像に香りを付けた際のアンケートによる主観評価実験 では，映像内容に適した香りであって，提示タイミングが 適している場合に高い臨場感の報告が得られた。つまり, 鑑賞者が映像から嗅覚の期待（嗅覚予期）を感じたときに, その期待を満たすように香りを提示できれば効果は高く, 一方, 映像から受ける印象に適さない香りを提示する, 又 は, 提示のタイミングがずれると違和感が生じ, 臨場感評 価が下がる結果を得た。このように, 臨場感はデリケート な感覚であり, 映像コンテンツ, 表示装置, 香り提示手段 の整合がとれ，かつ，鑑賞者が映像に集中しているときに 得られると思われる。映像に集中しているときには, 視線 の動きにも特徵が見られると思われるので, 香りを付加し たときの注視点分布から誘目性, 臨場感などを検討するこ とにした。

\section{3. 視線検出を用いた香り付き映像の誘目性評価 実験}

〈3·1〉実験のねらい 対象映像に香りを付けると注 視点はどのように変化するのかを視線検出装置を用いて調 查した ${ }^{(11)}$ 。実験では, 一つの画面の中に香りを発生しない 性質の誘目性の高い物体 1 と香りを発生する性質がある誘 目性が低い物体 2 とを配置し, 被験者にその映像を鑑賞し てもらう。物体 1 に関連する香りを提示した場合と香りを 
提示しない場合の 2 種類の条件で，視線データを蓄積する。 実験後, 注視点分布を比較する。香りを提示しない場合は, 当然，誘目性の高い物体に視線が集まることになる。しか し，香り提示によって誘目性の低い物体にも注視点が移る ようであれば，香りに誘目性があると判断されると考えた。

〈3·2〉 実験環境図 3 に実験環境を示寸。20 インチ 画面に視覚対象となる映像を提示し, 視距離 $60 \mathrm{~cm}$ で鑑賞し てもらう。映像に集中できるように周囲を暗幕で囲い，妨 害音が入らないようにヘッドホンで映像に関連する音響を 提示した。視線検出装置は, 図 4 に示すようなへッドユニ ット（帽子）型（株式会社ナックイメージテクノロジー製, EMR-8B）を用いた。使用時はヘッドユニットを被り，眼下 に近赤外光カメラ式センサをセットし, 瞳孔像と角膜反射 像を捉える。これらの像の中心位置を特徵点として視線を 検出する。また, 頭部には視野カメラを装着し, 当該視野 映像の中の注視点を検出し出力する。キャリブレーション 後の視線検出精度は 1 度以下である。この注視点データか ら注視対象を同定し，対象物毎に注視時間を計測する。

香り提示装置は, 確実に香りを提示するためチューブ式 を用いた。医療用に使用されるカニューラと呼ばれるビニ ール製チューブの一部に香料を染み込ませた脱脂綿を入 れ，エアーポンプによって空気を通過させ，カニューラの 突出した穴の部分から鼻先へ香りを提示する。香りの種類 ごとに複数の管を用いている (図 4 参照)。香りを連続して 提示すると嗅覚順応が生じるため, エアーポンプとカニュ

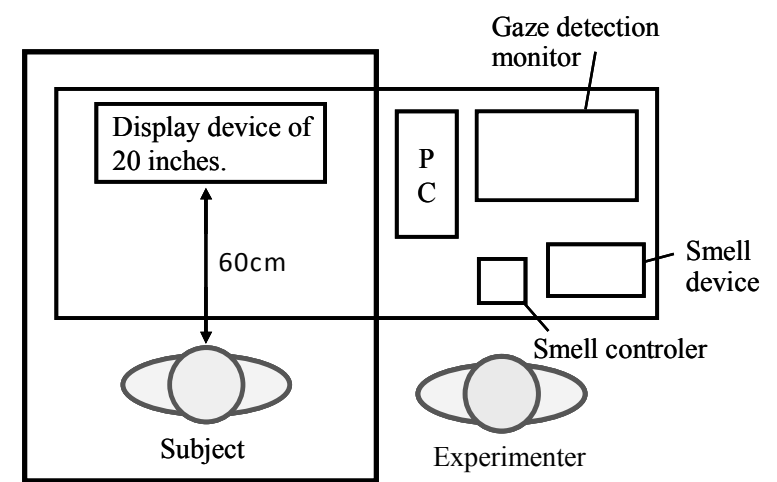

Blackout curtain

Fig. 3. Experimental environment.

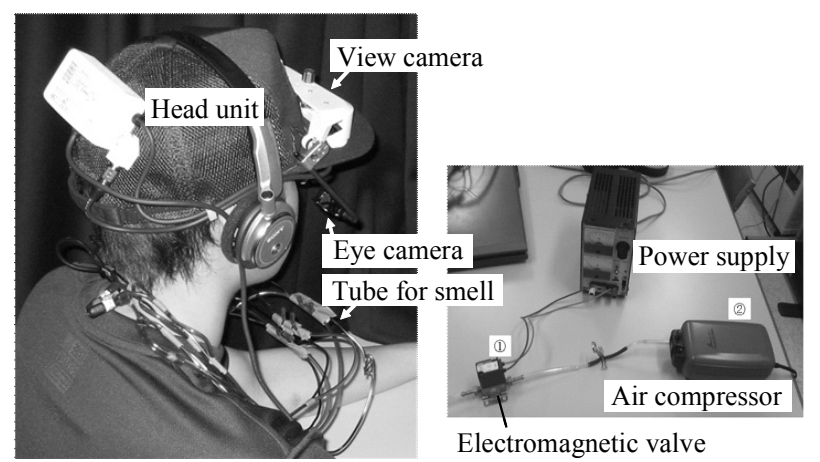

Fig. 4. Gaze detection system and smell presentation device.
ーラの間に小型電磁弁を使用し, 必要な時にのみ香りを提 示するように制御した。

〈3.3〉実験方法映像中の視覚対象に動きがない場 合, 誘目性は対象の大きさ, 色, 形状, 位置などに大きく 依存する。一方, 映像の中に動きがある場合は, 視線は動 いている物体にも強く誘導される。そこで, 視覚対象に動 きがない場合とある場合の 2 種類の映像を用いて注視点の 動きを計測した。また, 実験後, 印象について内省報告を 求めた。

（1）動きのない映像使用した映像は，二人の男女が 喫茶店でコーヒーを飲んでいるというストーリーで, 図 5 に示すように, シーンは 1 から 3 の順で変化する。シーン 1 とシーン 3 は同じ構図で, テーブルの真ん中付近に誘目性 の高い調味料や灰血などがあり，テーブルの隅に誘目性の 低い 2 つのコーヒーカップが置かれている。先の実験で, 映像に香りを付けた場合, 関心を示して睲孔が反応する時 間が 5〜15 秒程度であるため(4), 今回の実験では, シーン 1 , シーン 3 の香り提示時間は各々 10 秒に設定した。香料に は, インスタントコーヒー (MAXIM) を用いた。

シーン 1 ではコーヒーの香りを提示せず, シーン 3 でコ 一ヒーの香りを提示し, その 2 つのシーンについて視線を 検出した。注視点の軌跡は, 図 5 に示すように, 視野映像 内での視線を示すアイマークによって 1 画面ずつ（毎秒 30 枚）蓄積される。従って, 各々のシーンについて, 10 秒間 にどの対象物を，どの程度注視していたのかが分析できる。

(2) 動きのある映像図 6 に示寸ように, 果物を盛り 付けている様子を撮影した映像を使用した。この映像では, シーンチェンジはなく構図は大きく変化しない。画面中央 にメロンとグレープフルーツが配置され，その右側にリン ゴ, オレンジが並び, 画面下部にはパイナップルが配置さ れている。また, 香りを付加させる対象物の周りに果物を 盛り付けるための人の手が映り込んでいる為, 動きの多い 映像になっている。つまり, 動きのある人の手や暖色であ

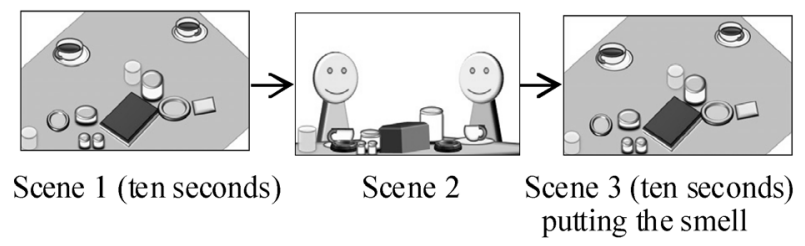

(a) Flow of presented scenes

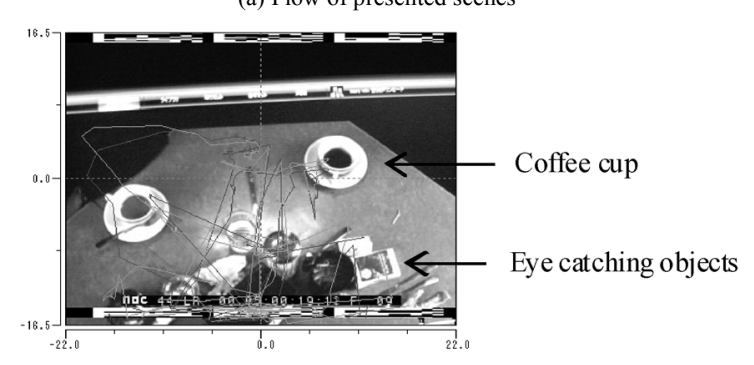

(b) Tracks of gaze points in the scene 3

Fig. 5. Presented image and gaze points detections. (Image with a little movement of object.) 


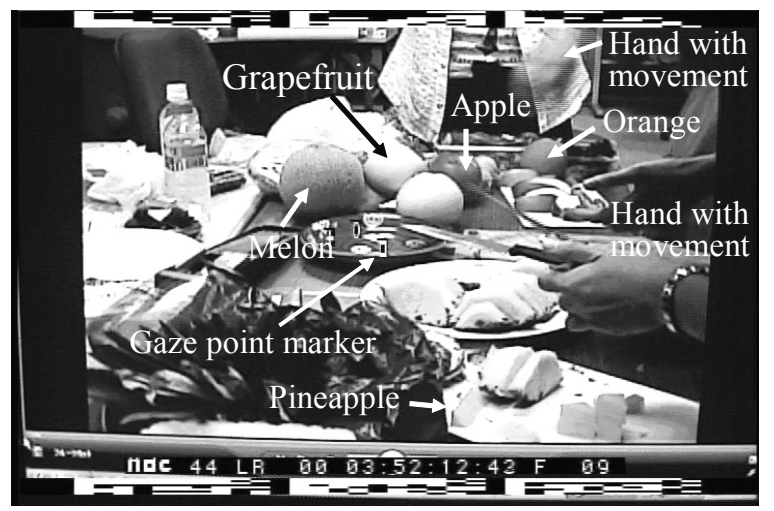

Fig. 6. Presented image with large movement of object.

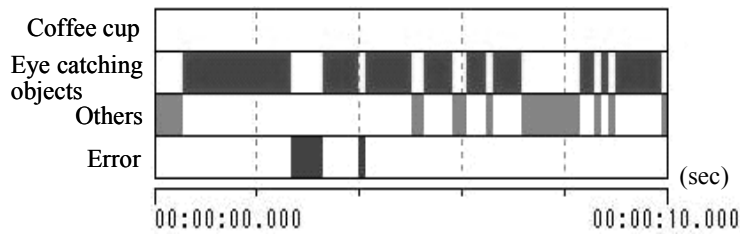

Scene 1; When two coffee cups and some eye catching objects are presented.

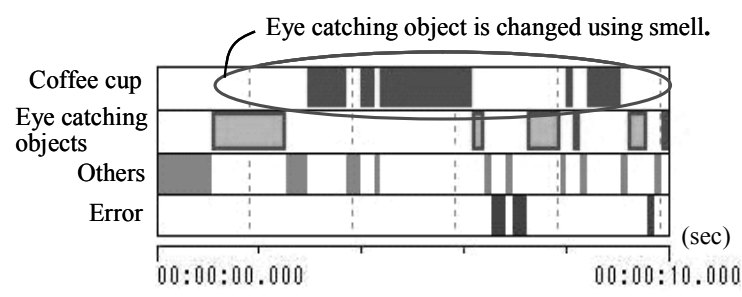

Scene 3; When putting the smell of coffee on the scene similar to scene 1 .

Fig. 7. Change of gazed target by smell presentation. (Image with a little movement of object.)

るリンゴ，オレンジなどは誘目性が非常に高く，逆にグレ ープフルーツはサイズも小さい為, 誘目性の低い物体とな る。ここで, グレープフルーツの香りを提示した場合と提 示しない場合での視線を比較した。香料は, Palm Tree 社製 の精油 (Citrus paradise) で, アメリカ産グレープフルーツの 果皮を圧搾して抽出したものである。映像に香りを付加す るタイミングは，実験開始初期の視線の不安定時間を避け るため, 被験者が映像の状況を把握するため約 20 秒を経過 した後, 香りを約 10 秒間提示した。被験者は, 両実験とも, 大学生 10 名（男 7 名, 女 3 名, 20 歳代）である。

\section{$\langle 3 \cdot 4\rangle \quad$ 注視点検出結果}

(1) 動きのない映像香りの有無による注視対象の違 いの一例（21 歳，女性）を図 7 に示す。縦軸は各対象の項 目を示し，横軸の帯長は当該対象を注視している時間を示 している。同図によって，被験者がどこを見ていたのか時 間軸でわかる。この被験者は，香りを提示しない場合は， 主に誘目性の高い物を注視しており，コーヒーカップは全 く注視していない (Scene1)。しかし，香りを提示した場合 は, Scene1 では誘目性が低かったコーヒーカップに高い頻

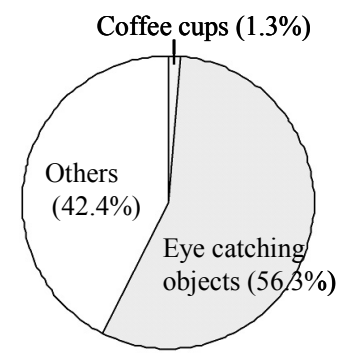

(a) Non smell

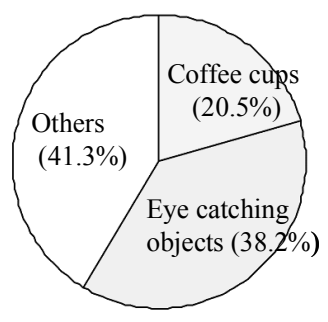

(b) Smell presentation
Fig. 8. Time spent gazing at object. (Average of ten subjects.)
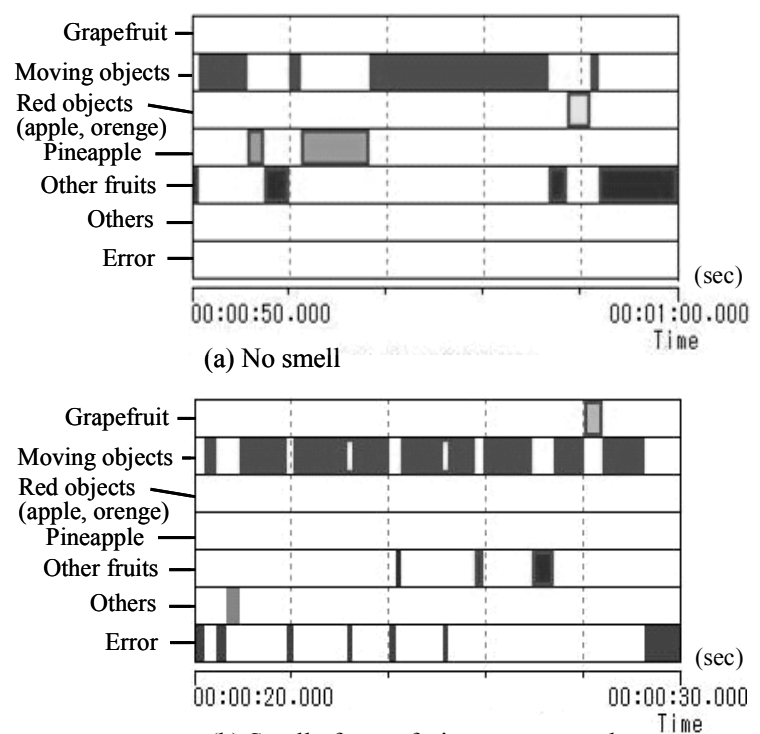

(b) Smell of grapefruit was presented.

Fig. 9. Change of gazed target by smell presentation. (Image with large movement of object.)
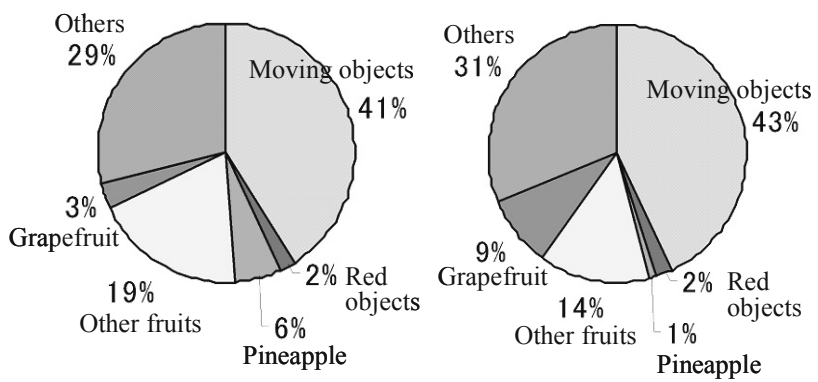

(a) No smell

(b) Smell of grapefruit was presented.

Fig. 10. Time spent gazing at object. (Average of ten subjects.)

\section{度で視線が誘導される様子が分かる (Scene3)。}

図 8 は, 10 名の被験者の上記データから, 注視点が 3 つ の対象物（コーヒーカップ, 誘目性対象, その他）の上に ある平均時間を求めた結果である。香りを付加することに より，コーヒーカップ注視時間が明らかに増加している。

(2) 動きのある映像香りの有無による注視対象の違 いの一例を図 9 に示す。この被験者（21 歳, 男性）は, 香 りを提示しない場合，グレープフルーツを全く注視してい ない(a)。香りを提示した場合も, 視線は, 主に動きのある 
ものに誘導されている(b)。しかし，僅かではあるがグレー プフルーツを注視していることが分かる。

図 10 は, 10 名の被験者について, 注視点が $6 つ$ つ対象物 (グレープフルーツ, 動きのある物体, 赤色の物体, パイン のへタと袋，その他のフルーツ, other）の上にある平均時 間を求めた結果である。動く物体を主に注視することが分 かる。香りなしと比較すると, グレープフルーツの香りを 提示によって,グレープフルーツを注視している時間が $3 \%$ から 9\%に増加した。

〈3.5〉 考 察 動きの少ない映像では, コーヒー の香りを提示することで，それまで誘目性が低かったコー ヒーカップに視線が強く誘導された。また，動きのある映 像でも，周囲に誘目性が高いものがあるにも関わらず，わ ずかだが誘目性の低いグレープフルーツに視線が誘導され る結果を得た。従来, 誘目性は, 大きさや色, 配置など, 主として視覚情報の特徴に対して調查されてきたが，嗅覚 が加わると, 視覚のみの場合より傾向が異なることが明ら かになった。映像の種類によって効果には差はあるものの, 香りを付けた物体を注視しやすい傾向がある。

なお，後者の実験結果で，香り有無の差は少ないように 見えるが，人は視野に動きのある物体が存在する場合，無 意識に当該物体を追う性質がある。鑑賞者は, 映像のスト ーリーを知らされていないので, 映像中の人物の動きを注 視し状況を把握しようとしていると思われ, 視線が動き対 象（人の手など）に集中寸るのは当然と言える。このよう な状況にあっては誘目性の低い物体（グレープフルーツな ぞ）は注視されにくく，通常であれば見逃してしまいがち であるが，香りを付けることによって，殆どの被験者が一 度はグレープフルーツを注視している。また, 被験者の内 省報告で，「香りがない映像では果物に関係なく手の動き に注目していたが，香り有では当該果物の存在を意識した， 過去の類似経験を想起した。などと回答している。広告映 像などへの応用を考える場合, 注視時間は短くても物体の 存在に気付かせる効果は重要である。

\section{4. 香り付加対象の位置と注視点分布}

〈4·1〉 実験のねらい 3 章の実験では, 動きの有無, 色などの誘目性要因と香り提示との関係について調べた が, 対象の位置も誘目性の重要な要因である。そこで, 香 り付加対象が画面の中央にある場合と端にある場合で香り 提示の影響がどの程度異なるかについて検討した。

〈4·2〉 実験方法 被験者実験に先立って, 図 11 に示 す 2 種類の提示映像を撮影した。映像内容は, 画面内の 3 名が，それぞれ異なるフルーツを持ち，それを食べるとい う一連の内容で, シーンチェンジはない。各映像の詳しい 内容と香り提示方法を以下に示す。

Image(i); 画面内の 3 名が, 左から順にオレンジ, チェリー, パイナップル持っている。左端のオレンジに関連する香り を提示する。香料は, Palm Tree 社製の精油, スウィートオ レンジ (Citrus sinensis), 果皮/圧搾／産地：アメリカであ

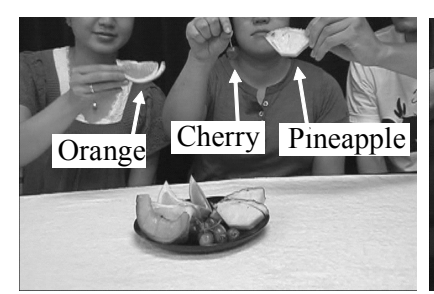

Image (i)

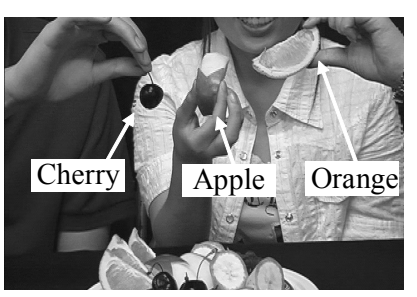

Image (ii)
(Smell of orenge was presented.) (Smell of apple was presented.)

Fig. 11. Experiment that inserts one smell on the scene where three people are eating three kinds of fruits.

る。

Image(ii); 画面内の 3 名が, 左から順にチェリー, リンゴ, オレンジ持っている。中央のリンゴに関連する香りを提示 する。香料は, 同社の精油, アップル (Malus pumila), 果実 /水蒸気蒸留/産地 : アメリカである。

画面の中の対象に関連する前記香りを提示する場合と, しない場合の 2 種類の条件で視線データを蓄積し, 実験後, 注視点の動きや停留点を比較する。実験環境は, 3 章の実験 と同じで, 香り提示時間は 10 秒とした。被験者は大学生 9 名（男 7 名, 女 2 名, 20 歳代) である。実験後, 香り提示 の印象を内省報告してもらい, 更に時間を置いて実験の際 の記憶をアンケート調查した。

$\langle 4 \cdot 3\rangle$ 分析方法 提示映像にはシーンチェンジはな いので, 注視時間分析だけでなく, 停留点時間分析も行っ た。停留点とは, 視野映像の中で, 視線がどこにあるのか を示すアイマークが物体の認知に必要な最小時間以上, 一 定範囲内にある場合，その範囲を視線が留まった点と見な す処理である。また, 停留点時間は, 当該停留点の時間を 実験時間（10 秒間）に渡って累計する処理である。従って, 注視時間分析は, 対象の上に視線がある時間を全てデータ として扱うが, 停留点時間分析は, 対象が認知されたと考 えられる時間だけをデータとして扱う違いがある。停留点 時間分析の手順を以下に示す。

(1) 視野映像を表示対象の大きさを考慮して分割し, 停 留範囲を決める。また, 視野映像の最初の画像に対応する アイマークを開始点とする。

(2) 開始点の次の画像に対応するアイマークが停留範囲 内にあるか否かを確認する。

(a)範囲内にある場合は, 停留点候補として $(2)$ 一戻り, ま た次のアイマークを判定する。

(b)範囲外にある場合は, 判定した画像の前で停留が終了 したとして $(3)$ へ行く

(3) 判定し終わった画像数から停留時間を算出, 予め設 定した最少時間と比較する。算出した停留時間が, 最少時 間以上であれば, 停留点と判定して $(4)$ 一行く。

(4) (2)で最後の判定に使用したアイマークを新たな開 始点として $(2)$ 一戻る。

停留点が, 判定し終わった停留範囲に再び戻った場合は すでに算出してある停留時間に加算される。以上の作業を 
繰り返すことで，各範囲内の停留点が算出できる。

本実験では，停留範囲は各フルーツが適度に分かれる 8 $\times 8$ の 64 分割にし, 物体認知に必要な最小時間は, $0.1[\mathrm{sec}]$ に設定した ${ }^{(12)}$ 。

\section{$\langle 4 \cdot 4\rangle$ 実験結果}

$\langle 4 \cdot 4 \cdot 1\rangle$ 停留点時間分析結果 前記スウィートオレ ンジ香料を提示した場合と，提示しない場合の停留点時間 分析の結果を図 12 image(i)に示す。同図は, 9 名の被験者の 平均を示している。香りがない場合，停留点時間は，チェ リー，オレンジ，パイナップルの順であるが，香りを付け るとオレンジに最も長く停留する。オレンジについて，香 りの有無で比較すると，香りなしの場合 0.46 秒であったも のが，香りを付けると 0.83 秒となり $45 \%$ 増加した。被験者 は画面に正対しており，正面に視線がある場合，オレンジ は周辺視で捉えられることになるが，オレンジへの関心が 高まり，横目，又は，顔を当該対象に向け長い時間中心視

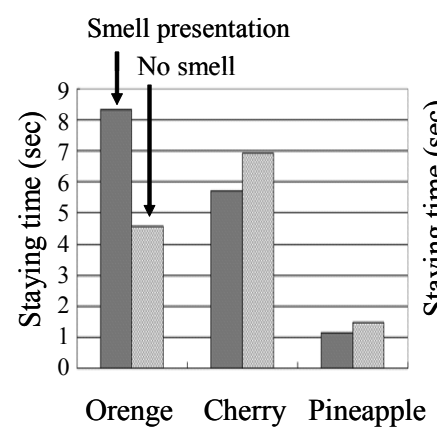

Image (i)

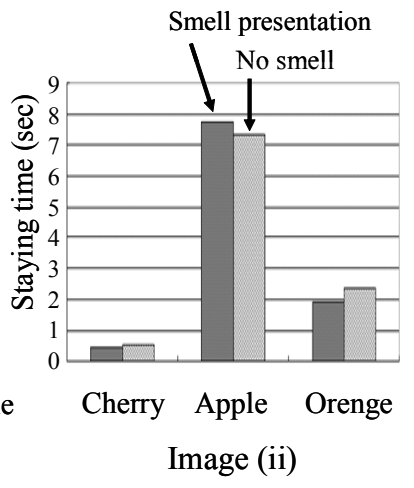

Fig. 12. Analysis results of gaze staying time.

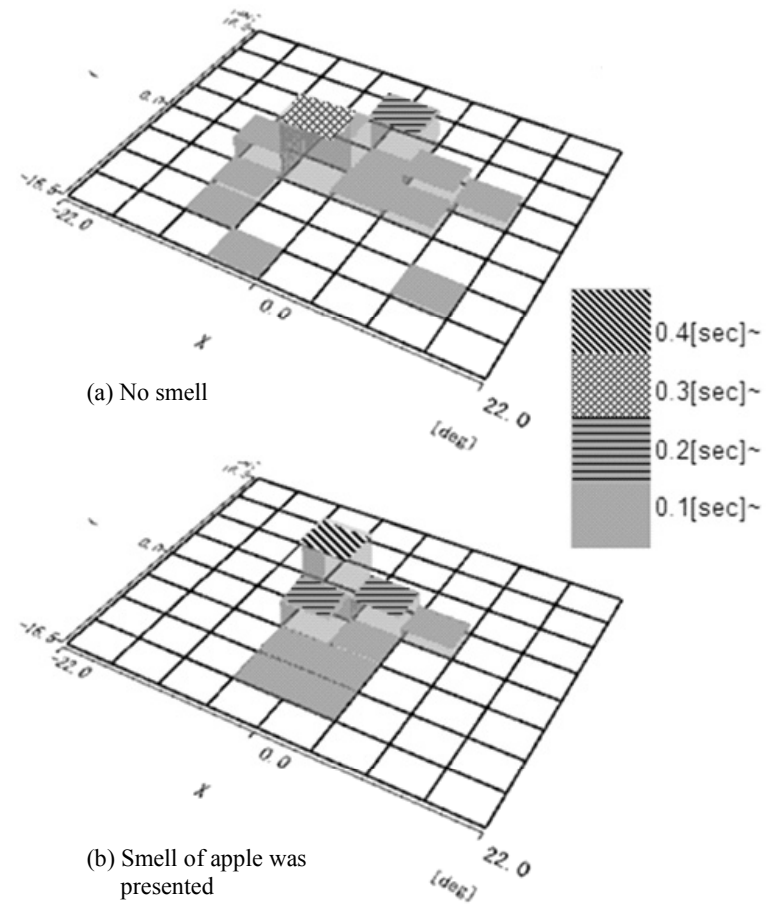

Fig. 13. Gaze staying time according to the area of screen on which the image(ii) was displayed.
で捉えていることが分かる。

前記アップル香料を提示した場合と，提示しない場合の 停留点時間分析の結果を図 12 image(ii)に示す。リンゴは正 面に表示されているため, 香りの有無によらず長く停留す るが，香りを提示しなかった場合（0.73 秒）に比心゙，香り を提示すると 0.77 秒と $5 \%$ 程増加した。なお, 停留点の最 低時間を 0.1 秒としているのに，チェリーの停留時間が 0.1 秒以下なのは, 被験者 9 名の平均を示しているためである。 チェリーに全く停留しない被験者も居る。

図 13 は, image(ii)の場合の停留時間を 3 次元表現した結 果である。格子面が画面に対応し, 棒グラフが当該格子領 域に停留した時間を示している。香りの有無を比較すると, 香りがない場合は，停留点にばらつきが見られるが，香り を提示するとフルーツが表示されている領域，特に，リン ゴが表示されている領域を中心に停留していることが分か る。

$\langle 4 \cdot 4 \cdot 2\rangle$ 注視時間分析結果 図 14 に, image(i) と image(ii)を鑑賞中の注視時間分析結果（9名の平均值）を示 す。停留点時間分析結果と同様な傾向であるが，香り有無 の差は，注視時間分析結果の方が大きくなっている。例え ば, 図 12 image(i)において, オレンジへの停留点時間は, 香 りなしに対して有りは約 50\%増えているが, 図 14 image(i) において，オレンジへの注視時間は，香りなしに対して有 りは2 倍以上増えている。また, 図 12 image(ii)において, リンゴ停留点時間の差は 5\%程度であるが, 図 14 image(ii) において, リンゴ注視時間の差は, 香り有りの方が $21 \%$ 増 えている。これは, 注視時間分析では, 停留点として判断

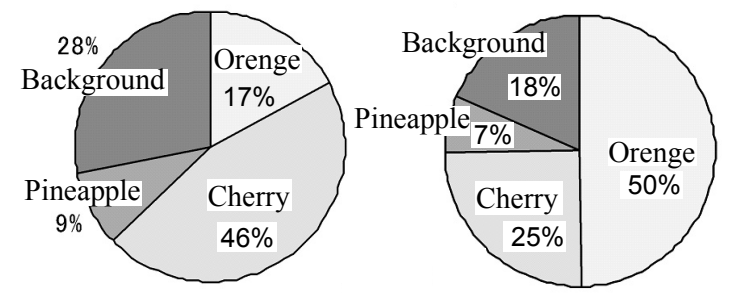

(a) No smell

(b) Smell of orenge was presented.

Image (i)

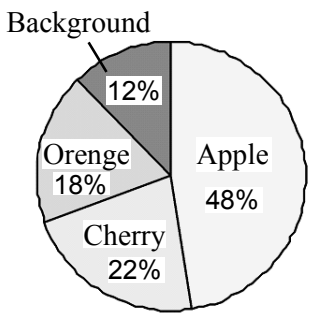

(a) No smell

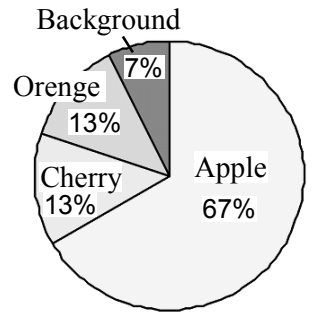

(b) Smell of apple was presented.
Image (ii)

Fig. 14. Time spent gazing at object. (Average of nine subjects.) 
されない視線データも含まれているためである。従って, オレンジやリンゴの注視時間が増えたと言うことは，当該 香り付加対象を中心に視線がよく動いていたことを意味 し，多くの情報を取り入れようとしていたことが伺える。

$\langle 4 \cdot 4 \cdot 3\rangle$ アンケート調査の結果実験から約半年後, 7 名の被験者に各果物について印象に残っている程度を尋 ねた。図 15 は, 各々, スウィートオレンジ香料付加の映像 とアップル香料付加の映像の結果である。香りを付けた対 象は, 何れの場合も5 点満点で, 5 点（非常に印象に残って いる）が 5 名， 4 点（やや印象に残っている）が 2 名であっ た。香りない対象に比べて明らかに強く印象に残っている ことが分かる。

$\langle 4 \cdot 5\rangle$ 考 察 image(i)の実験では, 視覚対象を画 面の端に表示しているので，周辺視野で捉える頻度が高く 通常は注視しにくい。このような場合であっても，香り提 示によってオレンジを探索する動作が見られ，当該対象に 停留する時間が増えた。従って, 香りには注視するのに不 利な位置にある対象にも視線を向けさせる誘目性効果があ ることが分かる。

image(ii)では, リンゴが画面中央にあり, 中心視野で捉え 易いため視線が当該対象に停留しやすいのは当然である が，図 13 の停留点の分布からは以下のことが考察される。 香りがない場合, 様々な対象に関心が分散し, 限られた情 報提示時間にできるだけ多くの情報を獲得しようとする姿 勢, 又は，映像の内容をできるだけ正確に理解しようとす る傾向が見られる。一方，香りを提示した場合は，当該対 象に関心が集中する様子が分かる。当該対象について自分 の過去の経験と結びつけて能動的に意識するようになるの ではないかと思われる。

実験後の内省報告では，「自然と香りがした果物に視線 が誘導されるのを感じた」, 「香りにより臨場感が高まり, 当該果物が食べたくなった」,「実験後でも香りがした映像 が記憶に残っている」などの上記仮説を支持する回答が得 られた。また, 香りを付けた対象については, 多くの被験 者が半年経過しても強く印象に残っていると回答してい る。

人は過去に香りに関する事象を経験している場合，後に その香りを嗅ぐと，それが引き金になって当時の記憶が想

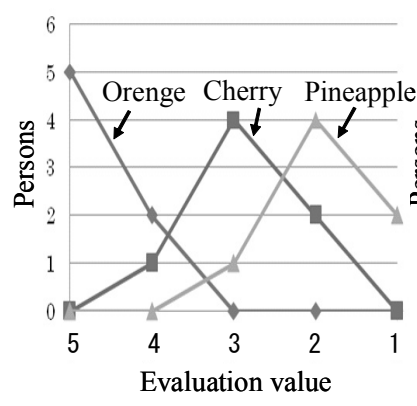

Image(i) which smell of orenge was presented.

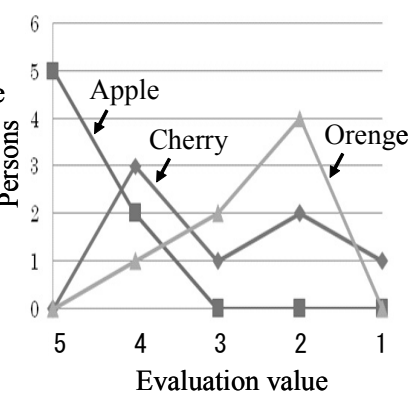

Image(ii) which smell of apple was presented.
Fig. 15. Results of the questionnaire after the experiments.
起される現象が知られている（プルースト効果と呼ばれ る)。また, 香りを提示しながら二次元配置を記憶させる実 験で, 当該実験の後, 寝ている時に再び同じ香りを提示す ると海馬が活性化し, 記憶を促進させる実験結果も報告さ れている(13)。

これらの知見を下に今回の実験を考察すると, 使用した 香料が，スウィートオレンジ，アップルなど良く知られた ものであったため, 無意識に過去の経験が想起され, 記憶 の定着に作用した可能性がある。このように, 香り付き映 像提示は，長期記憶にも有効と思われる。

\section{5. 香り付き VR コンテンツ鑑賞における記憶実験}

4 章は, 2 次元映像で視覚対象が比較的少ない場合の香り 付き実験であったが, 本章では, 没入型 VR 装置を用いて生 成した 3 次元空間において, より多くの対象が存在する場 合の香り提示による記憶力助長効果について調査した。

従来, 香りを用いたナビゲーションシステム開発などを 目的として, 被験者にVR 空間回遊映像を提示し経路を記憶 させる実験があり, 香りが経路の記憶を助長する結果が報 告されているが(5)(14), 本実験では, 空間に配置された対象そ のものを記憶する際に香り提示の効果を調べることが目的 である。

〈5・1〉 実験方法 3 次元 CG を用いて, 図 16 に示す ようなバーチャルショップ「花屋」を制作し, 当該ショッ プを図 17 に示す 3 つの大画面（前面，右側面，床面）から なる没入型立体表示装置 $\left(\right.$ HoloStage $\left.{ }^{\mathrm{TM}}\right)$ に等身大で投影し， 店内を移動できる環境を構築した。被験者は, 床面に立ち 液晶時分割眼鏡を掛け両眼立体視で周囲を観察できる。移 動操作は被験者の後ろに位置する実験者が行う。

被験者は, 店内を図 16 に示すようなルートに沿って移動

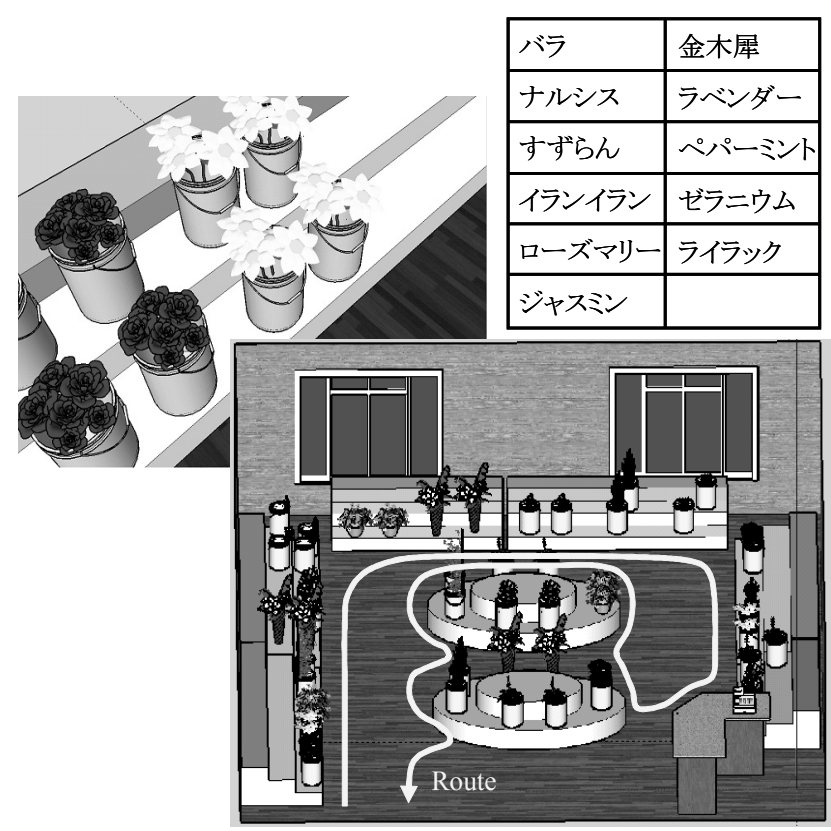

Fig. 16. Virtual flower shop produced by three-dimensional CG. 


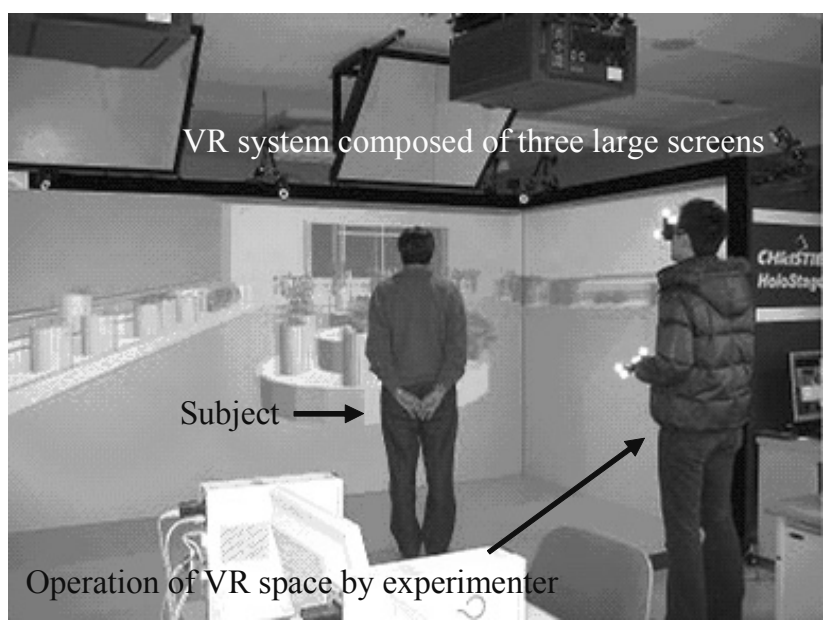

Fig. 17. Experimental environment with immersive VR system $\left(\right.$ HoloStage $\left.^{\mathrm{TM}}\right)$.

し，陳列棚に並べられた花の位置と名前を記憶する。ここ で，一つの花の前の立ち止まり時間は約 5 秒で，この間に 花の名前がアナウンスされ, 当該花の香りが提示される。 香り提示方法は, 液体香料を脱脂綿に含ませ小さな蓋付き 容器に入れておき, 提示が必要な際に蓋を開け, 被験者の 後ろから当該容器が見えないように手動で鼻の近くに香り を放出した。主に用いた香料は，Palm Tree 社製の精油（フ ラワー系) である。花はできるだけ形状が異なる 11 種類で, 1 種類の花あたり 2 鉢ずつ, 計 22 鉢がランダムに陳列され る。鉢から鉢への移動時間を含めると, 1 回の実験に要する 時間は 10 分弱である。

香りなし, 香り有の条件で時間を置いて 2 回行った。各々 の実験で花の配置を換え, 学習効果が生じないようにした。 店内を一周して花の名前を学習した後, テストでは, 店の 陳列棚の見取り図（花の代わりに空白の枠が並んだもの） に花の名前を記入させ, 名前と位置が共に正しい場合を正 解とした。被験者は, 大学生 12 名（男 6 名, 女 6 名）であ る。

〈5·2〉実験結果図 18 に, 花の種類別の正解率を示 す。 1 種類の花当たり 2 鉢ずつあるので, 1 つの種類の花の 前には，24名が立ち寄る。1 名正解ならば，正解率は 4\%程 度となる。香りを付けない場合の実験 (a)では,「バラ」,「ラ ベンダー」,「すずらん」の順で, 知名度の高い花の正解率 が高かった（同図，右側の棒グラフ）。また，花の種類によ って正解率に大きなばらつきが出た。一方, 香り有(b) では, 「ジャスミン」,「金木犀」, 「イランイラン」, 「バラ」の順 で, 特徵的な香りがする花の正解率が高く, 正解率のばら つきは少なかった（左側の棒グラフ）。平均的な正解率は, 香りなしが $23 \%$, 香り有は $36 \%$ で, 香りを付けることによ って $13 \%$ 向上した。

$\langle 5 \cdot 3\rangle$ 考 察今回の実験では, 視覚 (花の像), 聴覚 (花の名前) による 2 刺激提示よりも, 視覚, 聴覚, 嗅覚（花の香り）による 3 刺激提示の方が, 正解率が高い 結果であるため, 被験者に与えられた情報が多い程記憶し (b) Smell presentation

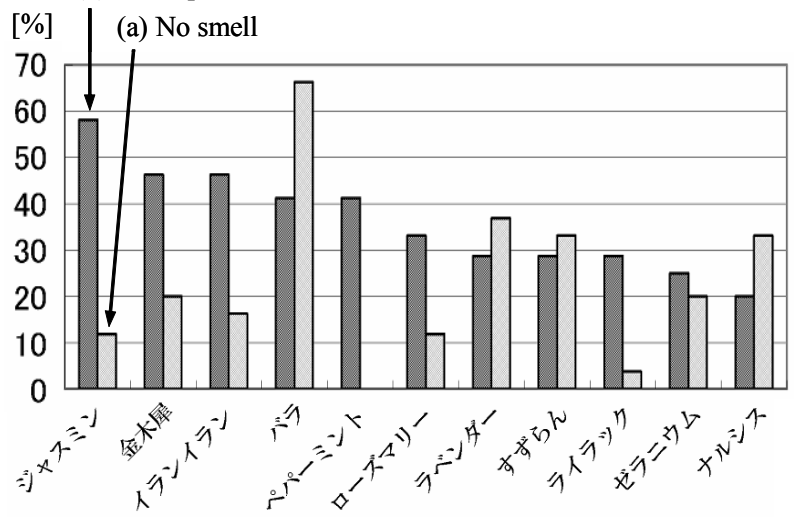

Fig. 18. Correct answer rate in flower name storage experiment.

易いと言える。また, 形, 色, 香りなどに馴染みのある対 象ほど良く記憶されている。例えば，バラは香りなしでも 有でも正解率は高い。

一方，ペパーミントは，普段見る機会が少ないため, 香 りなしの場合正解者は居なかったが, 香り有では㸚やかで 身近に接する香りなので, 正解率が高くなる。このように, 無意識に過去の経験が想起され, 記憶に影響したのではな いかと思われる。

\section{6. おわりに}

映像に香りを付けるシステムについて現状の取り組みを 述べ, 当該システムの意義を明らかにするため, 視覚対象 への誘目性, 臨場感, 及び, 記憶力向上について評価した。

今回の実験では, 視覚対象が飲食物や花など香りを強く 伴うものであったが, 適した香りを付加すると, 視線は当 該対象に誘導されやすく, 記憶されやすいことが明らかに なった。注視点時間分析, 停留点時間分析の結果からは, 香りがない場合, 被験者の視線はできるだけ多くの情報を 得ようとして広い範囲を頻繁に移動する傾向があり，一方， 香りがある場合は, 視線は当該対象に停留しやすい傾向が ある。このときのアンケート調査では, 映像に集中でき臨 場感が向上した, 過去の類似経験を想起し「食べたくなっ た」などの報告が得られた。香りを付けることによって， 鑑賞者は能動的に情報を得ようとし，これが臨場感にも繋 がるように思える。

今後, システムの完成には, 表示装置と香り提示装置の 一体的構成法などが課題となる。また, 香りと誘目性との 関連性をさらに調査し, 誘目性の要素を数值化すれば, ど の要素の組み合わせによって誘目性を高めることができる かを明らかにでき, 誘目性マニュアルが作成できると思わ れる。マルチモーダルな情報提示によって, 視線が誘導で きるのであれば，様々な応用が考えられる。例えば，テレ ビコマーシャル，デジタルサイネージ（電子街頭広告）な どの分野で, 注目して欲しい商品映像に香りを付けて提示 し, その商品への関心を高め, 記憶に留めてもらうなどの 
応用が考えられる。効率よく注目させるコンテンツの作成 方法やミドルウェアを検討，提案していきたい。

\section{謝 辞}

本研究を進めるに当たり，実験にご協力頂きました東海 大学技術員吹浦哲教氏，及び，データ整理にご協力頂きま した東海大学情報メディア学科の学生諸君に感謝申し上げ ます。本研究の一部は, 文科省科学研究補助金（基盤研究 (C) 19500179）の支援による。

(平成 20 年 3 月 26 日受付，平成 20 年 6 月 25 日再受付)

\section{文献}

（1）外池光雄編著：「におい・香りの情報通信」, フレグランスジャーナ ル社 (2007)

(2) Y. Yanagida, S. Kawato, H. Noma, A. Tomono, and N. Tetsutani : "Projection-Based Olfactory Display with Nose Tracking", Proceedings of IEEE Virtual Reality 2004, pp.43-50 (2004)

(3) 伴野 明・伴野貴俊・岩波奈央・佐藤女かり・宮内伸介：「呼吸検出 を用いた空気方式香り発生装置の特性」, 電学ケミカルセンサ研資, CHS-06-29, pp.249-254 (2006-12)

（4）伴野 明・山本茂明・宇都宮緑・伊計大介・柳田康幸・保坂憲一:「匂 い付き映像メディアが内容理解に及ぼす効果」, ヒューマンインタフ ェースシンポジウム 2004, pp.249-254 (2004-10)

（5）伴野 明 - 中村啓佑 - 市村祐也 - 高橋一将 - 中泉文孝 - 柳田康幸 . 保坂憲—: 「懙営触覚提示による地理情報記憶支援に関する一考察」, ヒューマンインタフェースシンポジウム 2005, No.1312, pp.131-134 (2005-9)

（6）伴野 明・笹倉良太・矢島菜摘：「没入型 VR 環境における匂いが地 理空間の記憶に及ぼす影響」, 第 28 回 CG・可視化研究会 (CAVE 研 究会), pp.5-9 (2007-10)

（7）田中昭二・井上正之・井上誠喜・中津吉平：「誘目性に寄与寸る物理 的特徴量をもとにした画像注目領域の抽出」, 映像情報メディア学会 誌, Vol.52, No.6, pp.881-890 (1998-6)

（8）田中昭二・石若通利・井上正之・井上誠喜：「画像からの感性要因の 抽出: 注目領域の抽出法」, 人文科学とコンピュータ研究会報告, Vol.97, No.12, pp.49-54 (1997-2)

（9）杉山亜希子・高田一・松浦慶総：「視線移動を伴う場合の誘目性に 関する研究」, 日本機械学会誌，山梨講演会講演論文集，Vol.2005, pp.133-134 (2005-10)

（10）伴野 明・柳田康幸・保坂憲一：「匂い提示情報付き映像コンテンツ 及びその上映システム」, 特願 2005-110078 (2005-4)

(11) 伴野 明・大竹俊弥・鈴木穣治・神田こより・竹石和広・柴 雄太 : 「視線検出を用いた香りつき映像の評価法に関する研究」，映像情報 メディア学会技術報告, Vol.31, No.52, pp.19-21 (2007-11)

(12) 大野健彦:「視線から何がわかるか一視線測定に基づく高次認知処理 の解明」, 日本認知科学会誌「認知科学」, Vol.9, No.4, pp.565-576 (2002)

(13) B. Rasch, C. Buchel, S. Gais, and J. Born : "Odor Cues During Slow-Wave Sleep Prompt Declarative Memory Consolidation", SCIENCE, Vol.315, pp.1426-1429 (2007-3)

(14) 萩内伸彦・林田和人・渡辺仁史: 「嗅覚による経路記憶力の助長効果 に関する研究」, 日本建築学会大会学術講演梗概集, E-1 分冊, pp.871-872 (2006)

伴 野 明 (正員) 1974 年 3 月山梨大学工学部電子工学

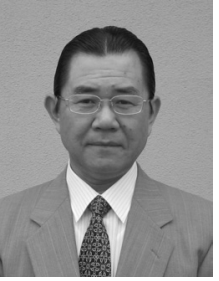
科卒業。1976 年 3 月同大学院修士課程修了。同 年, 日本電信電話公社 (現 NTT) に入社。以来, 研究所において, ヒューマンインタフェース, 臨場感通信の研究に従事。1987〜1991 年，国際 電気通信基礎技術研究所 (ATR) に出向。2000 年 4 月東海大学教授, 現在, 同大学院工学研究 科主任教授。丹羽高柳賞・論文賞, 工学教育賞 受賞。工学博士 (東工大)。電子情報通信学会, 映像情報メディア 学会, ヒューマンインタフェース学会などの会員。

神 田こより

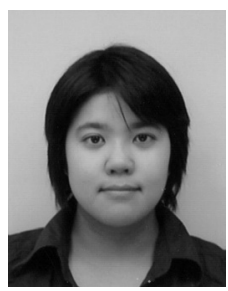

大 竹 俊 弥

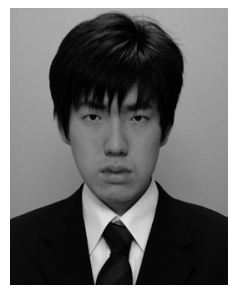

（非会員） 2008 年 3 月東海大学電子情報学部 情報メディア学科卒業。現在, 同大学大学院工 学研究科情報理工学専攻に在籍。在学中は, 視 線検出を用いた香り付き映像メディアの評価 法に関する研究に従事。 